\title{
PReS-FINAL-2307: Libman-Sacks endocarditis as a presentation for systemic lupus erythematous in an adolescent with isolated mitrial regurgitation and Noonan syndrome
}

\author{
SC Chen ${ }^{1 *}$, B Smith², M llina ${ }^{2}$, C Bowen ${ }^{3}$, N Martin $^{4}$ \\ From 20th Pediatric Rheumatology European Society (PReS) Congress \\ Ljubljana, Slovenia. 25-29 September 2013
}

\section{Introduction}

Systemic lupus erythematous (SLE) is a complex disease which is rare in childhood and can present insidiously. Libman-Sacks endocarditis (LSE) is a recognised cardiac manifestation of SLE with valvular abnormalities that are clinically silent prior to significant valve dysfunction. Multiple reports have associated isolated mitral regurgitation with SLE and the presence of antiphospholipid antibodies in SLE patients increases the prevalence of mitral valve regurgitation by three fold.

\section{Objectives}

To highlight awareness of Libman-Sacks endocarditis as a presentation of juvenile SLE

\section{Methods}

Case report

\section{Results}

We present a case of a 17 year old boy with phenotypic Noonans (SHOC2 mutation) who presented aged 14 with a pericardial effusion, verging on tamponade and requiring surgical drainage and diuretic therapy. A previous cardiac ultrasound aged 12 had shown no significant abnormality. One year later he developed mitral regurgitation, deteriorating over the following 18 months with the development of increasingly severe congestive cardiac failure (WHO class IV). Further history revealed new onset headaches and difficulty in concentration as well as a history of intermittent arthralgia. There were no rash, fever or mouth ulcers.

${ }^{1}$ Paediatrics, Royal Hospital for Sick Children, Glasgow, UK

Full list of author information is available at the end of the article
Investigations demonstrated lymphopenia, prolonged APTT with positive lupus anticoagulant and anticardiolipin antibodies, raised immunoglobulin levels, low C4, persistently raised ESR but normal CRP as well as strongly positive ANA(1:2560) and anti-DNA antibody $(86 \mathrm{IU} / \mathrm{ml})$. Blood cultures, throat swabs and viral serology were negative. A diagnosis of SLE with Libman-Sacks endocarditis was made. There was no evidence of renal involvement. A course of intravenous methylprednisolone followed by oral steroids was given to minimise active inflammation prior to mitral valve replacement with a mechanical valve. Histopathology of the damaged mitral valve demonstrated fibrinous deposits with neovascularisation and myxoid degenerative changes, consistent with LSE. He made a good recovery following surgery with resolution of his dyspnoea. He has been anticoagulated with warfarin and commenced on hydroxychloroquine and mycophenolate mofetil for maintenance immunosuppression.

\section{Conclusion}

LSE is rare in childhood with only six previous cases described in the literature. In adults with SLE the prevalence of progressive valvular abnormalities is higher when SLE is associated with antiphospholipid antibodies. Interestingly, SHOC2 mutation is associated with congenital mitral valve defects but acquired mitral valve disease has not been reported.

This case highlights the difficulties and potential delays in diagnosing SLE due to its varied and often insiduous presentation and demonstrates that LSE can occur in children with lupus. It also reaffirms the importance of considering autoimmune inflammatory conditions in cases of pericarditis with no evidence of an infectious cause. 


\section{Disclosure of interest}

None declared.

\section{Authors' details}

${ }^{1}$ Paediatrics, Royal Hospital for Sick Children, Glasgow, UK. ${ }^{2}$ Cardiology, Royal

Hospital for Sick Children, Glasgow, UK. ${ }^{3}$ Pathology, Royal Hospital for Sick

Children, Glasgow, UK. ${ }^{4}$ Rheumatology, Royal Hospital for Sick Children,

Glasgow, UK

Published: 5 December 2013

doi:10.1186/1546-0096-11-S2-P297

Cite this article as: Chen et al:: PReS-FINAL-2307: Libman-Sacks

endocarditis as a presentation for systemic lupus erythematous in an

adolescent with isolated mitrial regurgitation and Noonan syndrome.

Pediatric Rheumatology 2013 11(Suppl 2):P297.

Submit your next manuscript to BioMed Central and take full advantage of:

- Convenient online submission

- Thorough peer review

- No space constraints or color figure charges

- Immediate publication on acceptance

- Inclusion in PubMed, CAS, Scopus and Google Scholar

- Research which is freely available for redistribution

Submit your manuscript at www.biomedcentral.com/submit
Ciomed Central 